\title{
The Microstructure Testing of Brass Materials on the Liquified Petroleum Gas (LPG) Gas Valve
}

\author{
Muhamad Emiriza ${ }^{1}$, Winda Sri Jaman ${ }^{2}$, Nur Ichsan Sumardani ${ }^{1 *}$, WS Mada Sanjaya ${ }^{1}$ \\ ${ }^{1}$ Universitas Islam Negeri Sunan Gunung Djati Bandung \\ ${ }^{2}$ Balai Besar Logam dan Mesin (BBLM), Bandung
}

\begin{abstract}
In this study brass used as a sample is brass which is used as a raw material for LPG (Liquified Petroleum Gas) valves. Two samples were taken which were prepared before the composition test and microstructure test. From the results of the micro test, it is found that the brass phase structure is the $\alpha$ proeutectic phase and the $\beta$ phase. The proeutectic phase $\alpha$ has an FCC structure while the $\beta$ phase has a BCC structure. There are also black dots which are Lead with different percentages for each sample. Lead tends to be in the particleshapedside
\end{abstract}

\begin{abstract}
ABSTRAK
Pada penelitian ini kuningan yang digunakan sebagai sampel adalah kuningan yang digunakan sebagai bahan baku katup Gas LPG (Liquified Petroleum Gas). Diambil dua sampel yang terlebih dahulu dilakukan proses preparasi sebelum uji komposisi dan uji struktur mikro. Dari hasil pengujian mikro didapatlah struktur fasa kuningan yaitu fasa proeutektik $\alpha$ dan fasa $\beta$. Fasa proeutektik $\alpha$ mempunyai struktur FCC sedangkan fasa $\beta$ mempunyai struktur BCC.Terdapat juga titik-titik hitam yang merupakan Timbal dengan persentase yang berbeda untuk tiap sampelnya. Timbal cenderung berada pada bagian samping berbentuk partikel.
\end{abstract}

CONTACT

ichsan.sumardani@gmail.com

KEYWORDS

Microstructure, Brass, Lead

Received: $26 / 01 / 2021$

Revised: 22/02/2021

Accepted: $30 / 03 / 2021$

Online: $25 / 04 / 2021$

Published: 30/04/2021

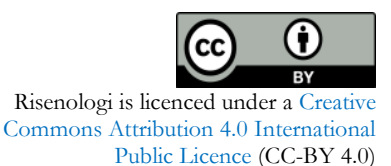

\section{INTRODUCTION}

Ilmu logam merupakan ilmu mengenai bahan bahan logam yang mencakup teori dasar, pengamatan, pengukuran, dan pengujian. Pengujian bahan logam saat ini semakin berkembang luas baik dalam kontruksi, permesinan, bangunan, maupun bidang lainnya. Hal ini disebabkan oleh sifat logam yang bisa diubah sehingga pengetahuan pun terus berkembang. Proses pengujian logam merupakan proses pemeriksaan bahan-bahan untuk mengetahui sifat dan karakteristik yang meliputi sifat mekanik, sifat fisik, dan sifat kimia serta unsur-unsur yang terdapat di dalamnya (Nugroho, 2010).

Pengujian struktur makro merupakan pengujian yang dapat dilihat dengan penglihatan secara langsung menggunakan alat ukur seperti penggaris. Sementara itu, pengujian struktur mikro merupakan pengujian yang dilakukan untuk mengetahui struktur material yang tidak dapat dilihat secara langsung dengan kasat mata. Pengujian struktur mikro ini dilakukan dengan menggunakan bantuan alat seperti mikroskop, baik mikroskop optic maupun mikroskop electron (Setiawan, 2013).

Pengujian komposisi kimia pada logam merupakan pengujian untuk melihat komposisi kimia yang terdapat dalam sampel yang akan di uji. Komposisi kimia berarti unsur unsur yang terkandung dalam suatu bahan. Komposisi kimia tersebut dapat memperlihatkan kualitas produk uji (Nugroho, 2010).

Kuningan adalah logam yang merupakan campuran dari tembaga $(\mathrm{Cu})$ dan seng $(\mathrm{Zn})$. Tembaga merupakan komponen utama dari kuningan, dan kuningan biasanya diklasifikasikan sebagai paduan tembaga. Warna kuningan bervariasi dari coklat kemerahan gelap hingga ke cahaya kuning keperakan tergantung pada jumlah kadar seng. Seng lebih banyak mempengaruhi warna kuningan tersebut. Kuningan lebih kuat dan lebih keras dari pada tembaga, tetapi tidak sekuat atau sekeras baja (Konen and Fintov, 2012).

Identifikasi masalah berdasarkan penelitian yang telah dilakukan dalam pengujian Struktur Mikro Material Kuningan Pada Katup Gas LPG Balai Besar Logam dan Mesin (BBLM) adalah Mengetahui komposisi kimia apa saja dalam Katup Gas LPG logam Kuningan yang akan mempunyai pengaruh terhadap kinerja bahan baku logam kuningan tersebut dan mengetahui struktur mikro dan unsur apa saja yang ada dalam strukur mikro katup gas LPG logam kuningan. 


\section{METHODS}

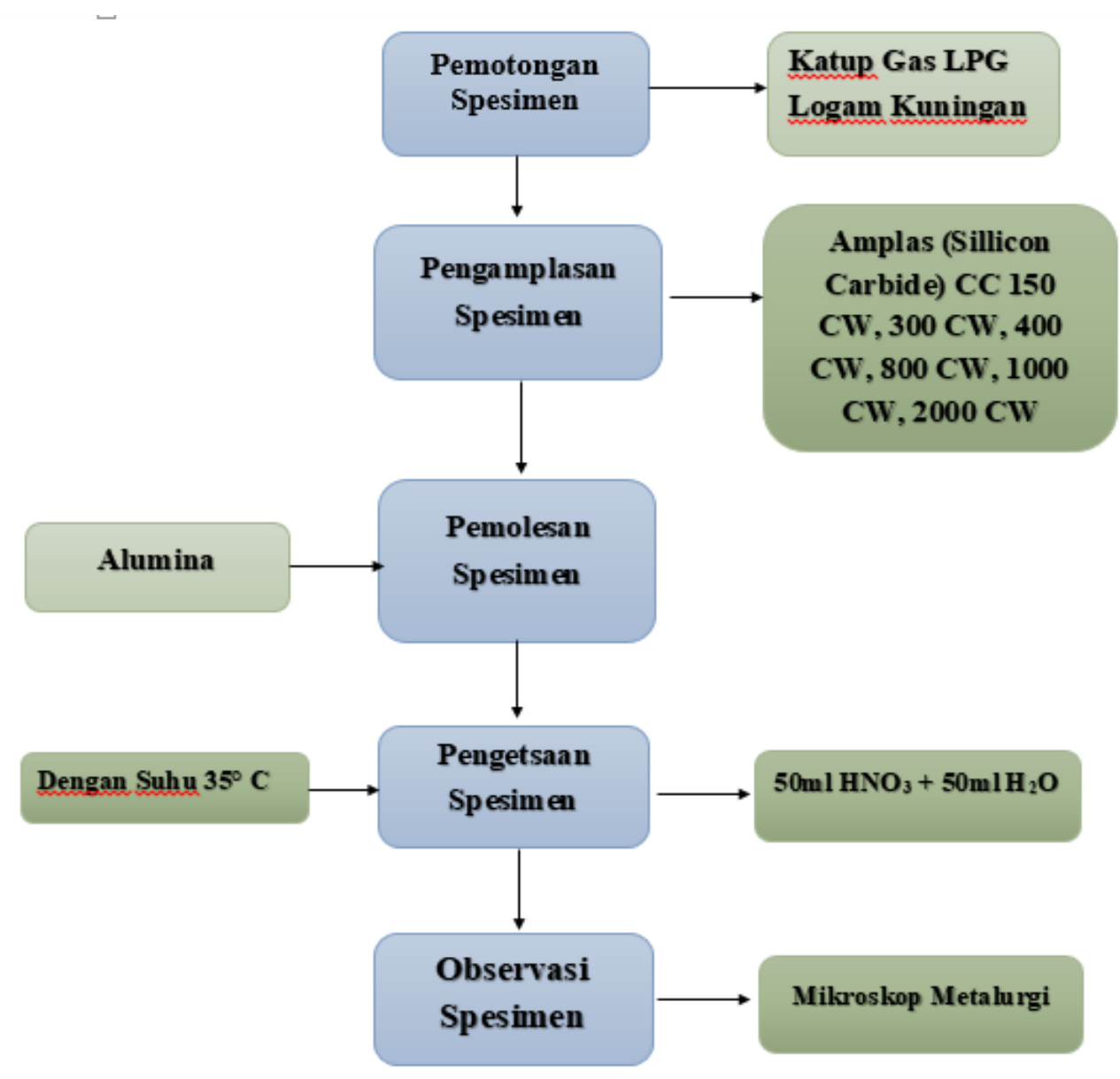

Gambar 1. Skema Pengujian Struktur Mikro pada Katup Gas LPG Logam Kuningan

Pada Gambar 1 menjelaskan tentang skema pengujian struktur mikro pada katup gas LPG logam Kuningan, langkah pertama yaitu pemotongan spesimen dalam hal ini sampel yang diuij adalah katup Gas LPG lalu setelah di potong lakukan pengamplasan, pada proses pengamplasan spesimen di amplas dengan enam kali amplas yang berbeda yaitu $150 \mathrm{CW}, 300 \mathrm{CW}, 400 \mathrm{CW}, 800 \mathrm{CW}, 1000 \mathrm{CW}, 2000 \mathrm{CW}$. Setelah diamplas spesimen di poles dengan menggunakan alumina untuk menghaluskan dan membersihkan sisa sisa amplas. Sesudah itu dilakukan pengetsaan dengan cairan $50 \mathrm{ml} \mathrm{HNO} 3+\mathrm{N} 2 \mathrm{O}$ dan dipanaskan sampai $35^{\circ} \mathrm{C}$ selama 10 detik saja. Terakhir lakukan pengamatan spesimen menggunakan mikroskop metalurgi.

Dalam pengujian ini dibutuhkan alat dan bahan seperti dalam Tabel 1 berikut.

Tabel 1. Alat dan Bahan

\begin{tabular}{cc}
\hline No & Alat dan Bahan \\
\hline 1. & Komputer \\
2. & Mikroskop optic \\
3. & Ampelas \\
4. & Gunting \\
5. & Polishing Machine \\
6. & Alat Pengering \\
7. & Penggaris \\
8. & Termometer \\
9. & Kompor Listrik \\
\hline
\end{tabular}




\section{RESULTS AND DISCUSSIONS}

Paduan $\mathrm{Cu}-\mathrm{Zn}$ dengan kandungan $\mathrm{Cu}$ sedikitnya 55\% dikenal dengan sebutan yang memiliki Kuningan.

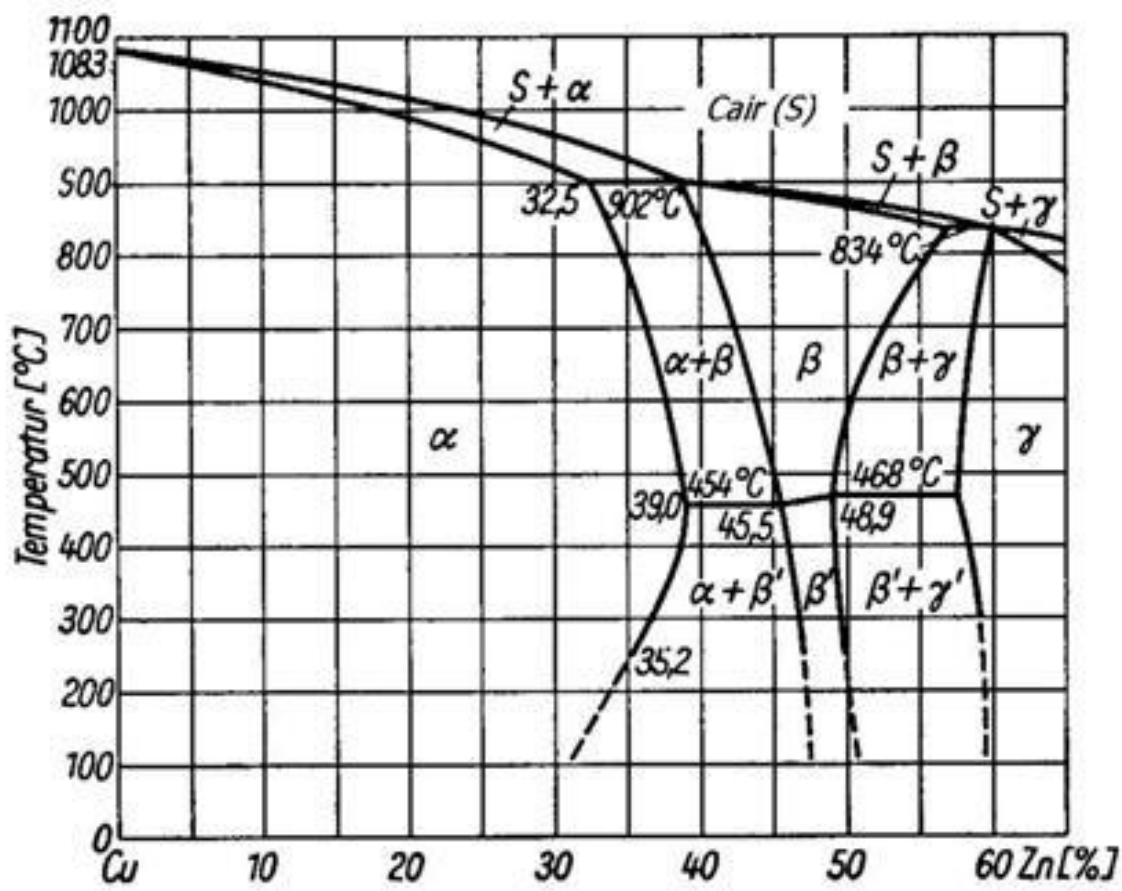

Gambar 2. Diagram Fasa Biner Cu-Zn (Setiawan, 2013)

Secara umum kuningan terdiri dari Kuningan $-\alpha \beta$. Matriks (struktur dasar) $\alpha$ dan kuningan- $\beta$ yang memiliki matriks. Dalam keadaan pada $\mathrm{Cu}$ mampu melarutkan $\mathrm{Zn}$ sangat banyak didalam kristal campuran. Pada temperatur $902{ }^{\circ} \mathrm{C}$ terjadi transformasi paritektik dimana $\mathrm{Zn}$ larut sebesar 32,5\%. Kelarutan ini meningkat sampai dengan temperatur sekitar $450^{\circ} \mathrm{C}$ menjadi $39 \%$ dan kemudian pada kondisi keseimbangan akan kembali menurun, yaitu pada proses pemanasan panjang dan pendinginan sangat lama (Pantazopoulos and Vazdirvanidis, 2008).

Gambar 2. menjelaskan proses pendinginan yang umum dicapai secara teknis, struktur kuningan dengan kandungan $\mathrm{Zn} \mathrm{39 \%}$ setelah perlakuan panas biasanya akan terdiri dari fasa $\alpha$ yang homogen tanpa ada sedikitpun fasa $\beta$. Kuningan inilah yang kemudian dikenal dengan kuningan $\alpha$ (alfa) yang memiliki sifet ulet namun cukup memiliki ketermesinan yang baik dengan unit sel FCC seperti pada umumnya panduan lembaga lainnya (Setiawan, 2013).

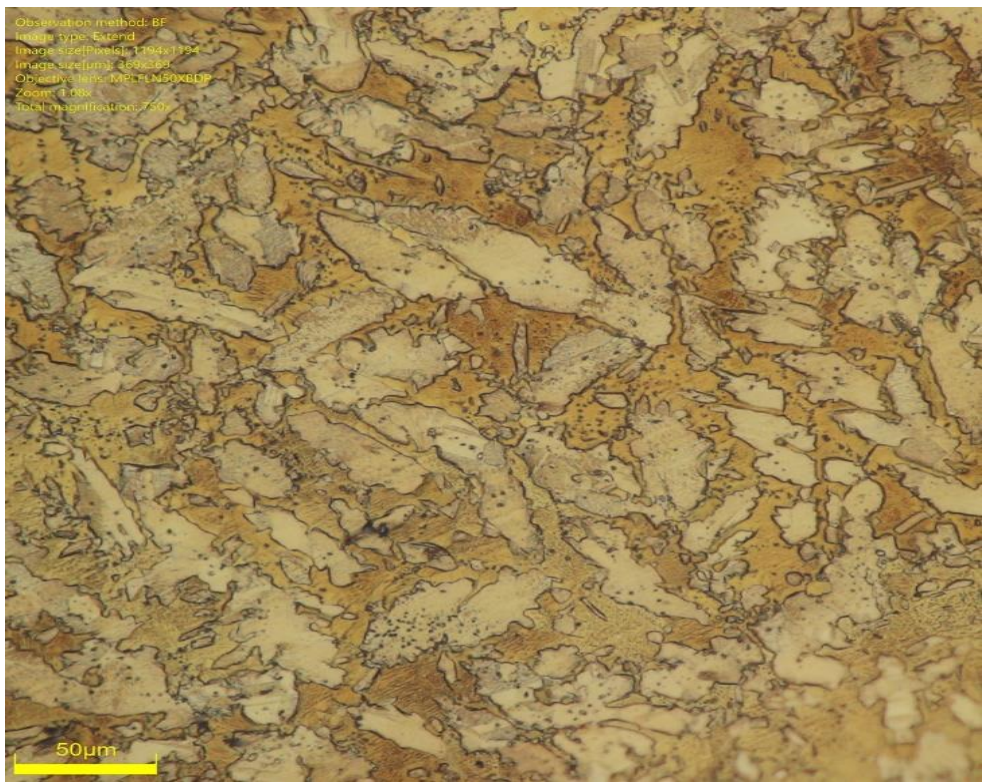

(a) 


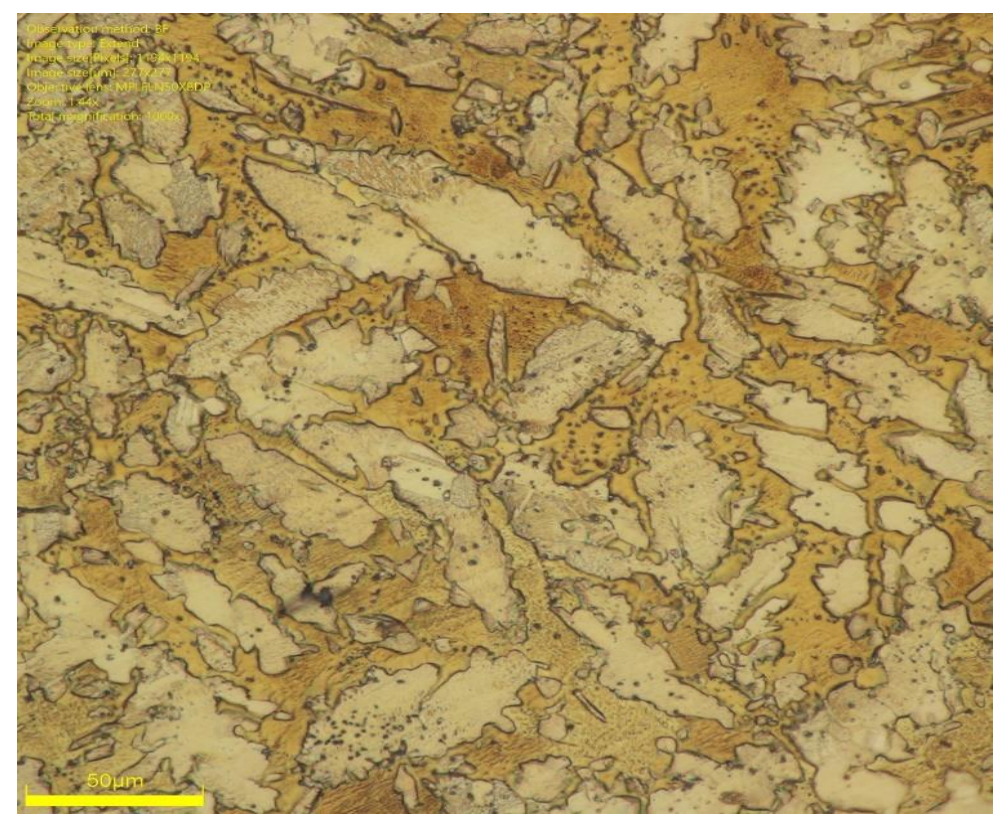

(b)

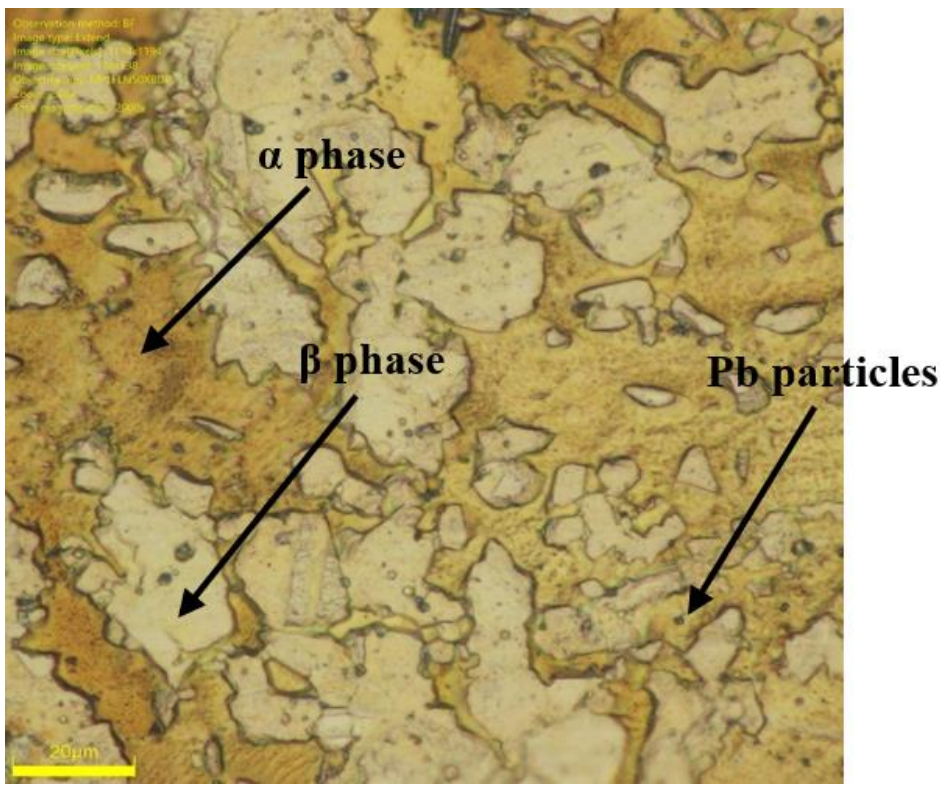

(c)

Gambar 3. (a) Struktur Mikro Sampel 1 Pembesaran 750x, (b) Struktur Mikro Sampel 1 Pembesaran 1000x, dan (c) Struktur Mikro Sampel 1 Pembesaran 2000x

Telah dilakukan pengamatan struktur mikro sampel 1 dengan tiga kali pembesaran, Gambar 3 (a) menunjukan struktur mikro dengan pembesaran 750x, Gambar 3 (b) menunjukan struktur mikro dengan pembesaran 1000x dan Gambar 3 (c) menunjukan struktur mikro dengan pembesaran 2000x. Dari pengamatan tersebut didapatlah struktur fasa proetektik $\alpha$ (bagian putih) dan fasa $\beta$ (bagian gelap). Fasa $\alpha$ preotektik mempunyai striktur FCC (Face Centered Cubic) sedangkan fasa $\beta$ mempunyai struktur BCC (Body Centered Cubic). Fasa $\beta$ mempengaruhi nilai keuletan dari kuningan, jika fasa $\beta$ menurun jumlahnya maka keuletan kuningan akan meningkat. Pada foto Struktur mikro tersebut terlihat dengan jelas fasa proeutektik $\alpha$ berbentuk memanjang. Titik-titik hitam merupakan Timbal dengan kadar 1,79\%. 


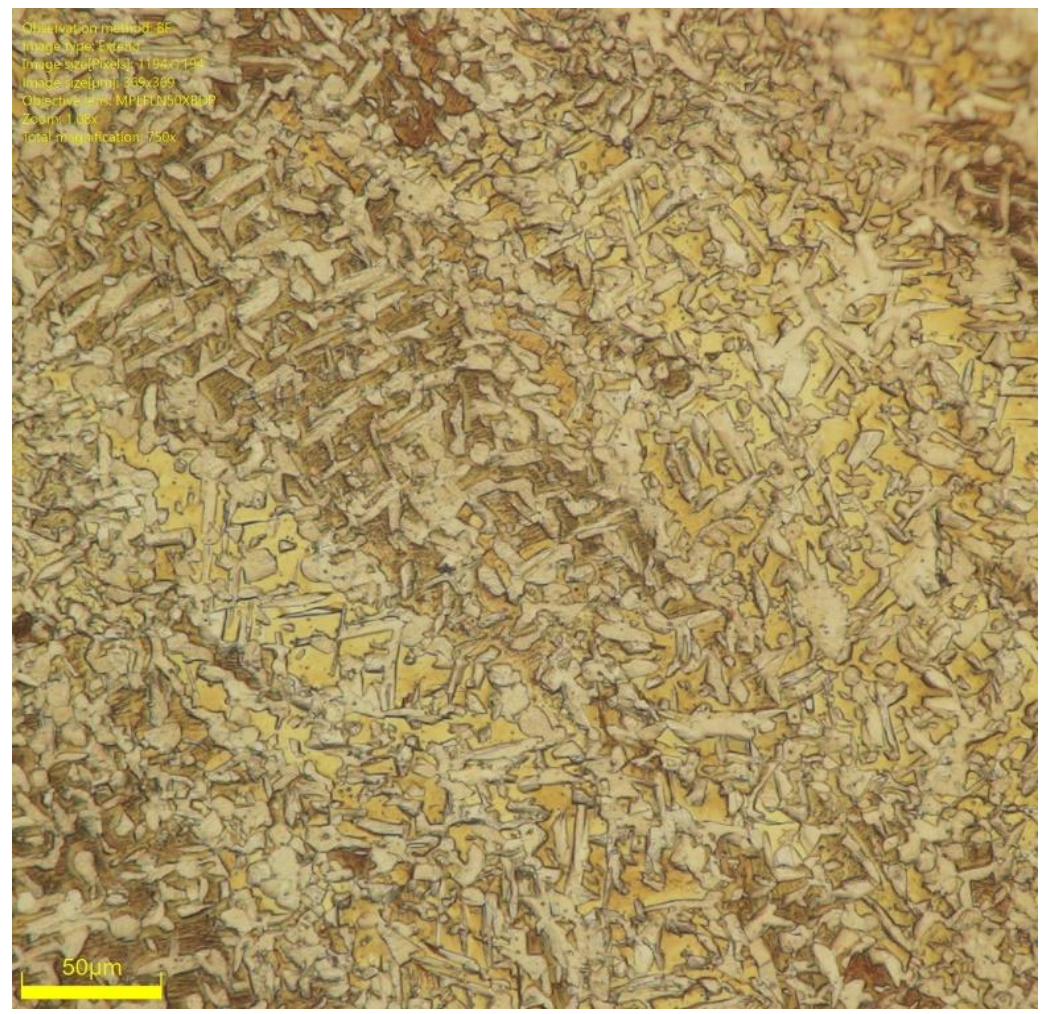

(a)

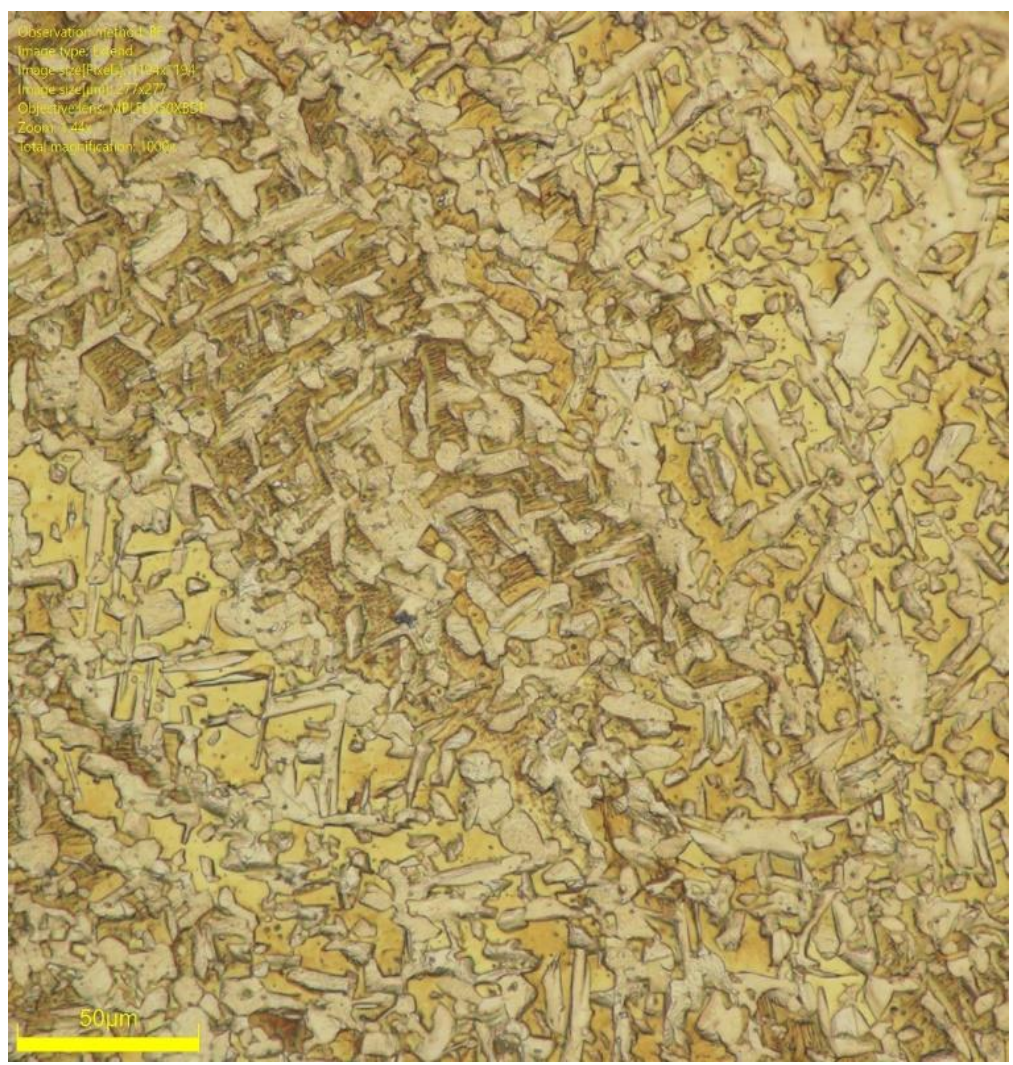

(b) 


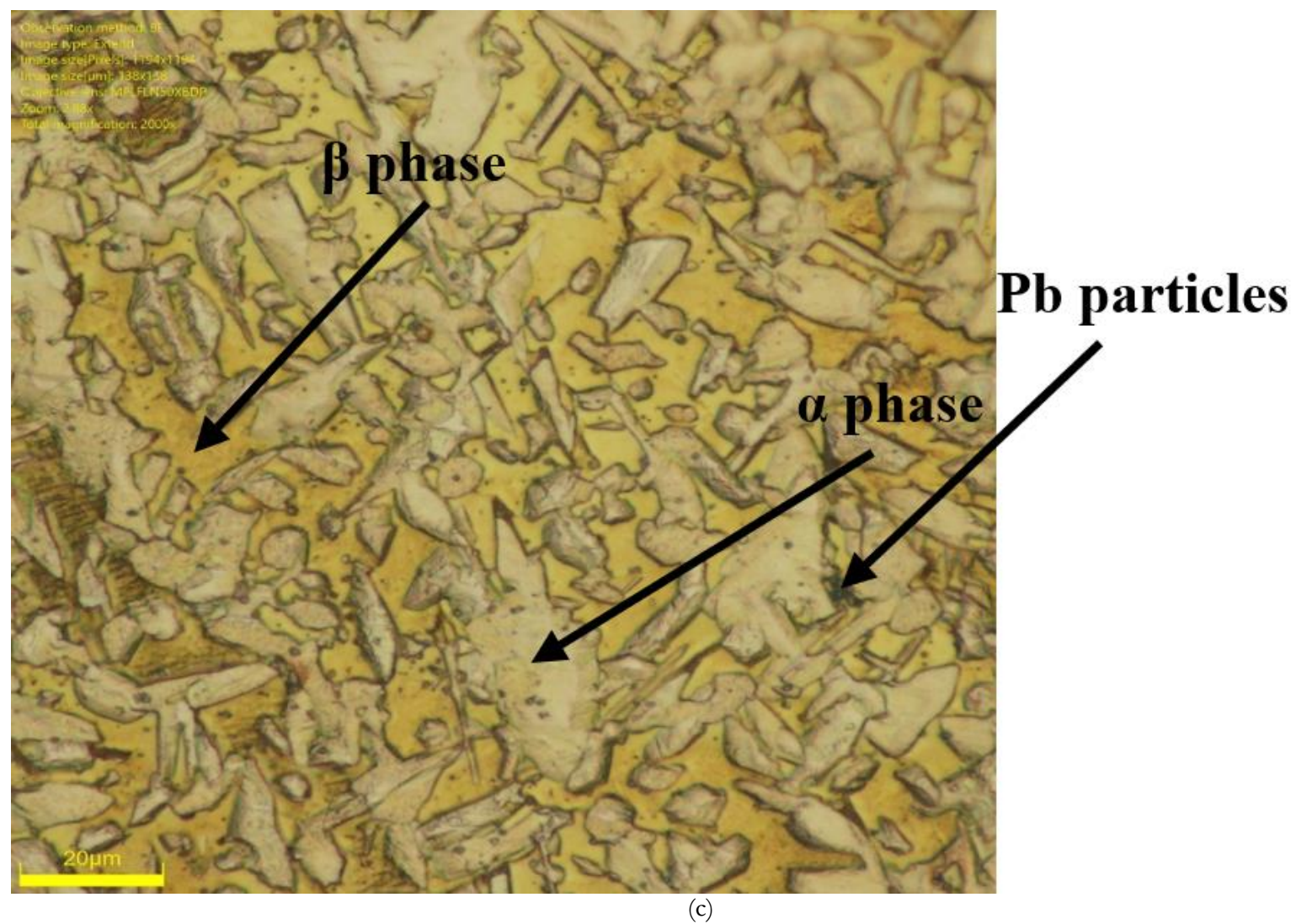

Gambar 4. (a) Struktur Mikro Sampel 2 Pembesaran 750x, (b) Struktur Mikro Sampel 2 Pembesaran 1000x, dan (c) Struktur Mikro Sampel 2 Pembesaran 2000x

Pengamatan pada sampel kedua pun sama Gambar 4 (a) menunjukan struktur mikro dengan pembesaran 750x, Gambar 4 (b) menunjukan struktur mikro dengan pembesaran 100x dan Gambar 4 (c) menunjukan struktur mikro dengan pembesaran 2000x. Namun pada pengamatan struktur mikro sampel kedua terdapat fasa proeutektik $\alpha$ menjadi semakin kecil dan sedikit memanjang namun jumlahnya cenderung meningkat dan fasa $\beta$ cenderung menurun, hal disebut dikarenakan perbedaan sampel yang dipakai. Adapun sampel kedua didapati kadar karbon Timbal sebesar 1,44\% untuk lebih jelasnya dituliskan dalam Tabel 2 berikut.

Tabel 2. Data komposisi sampel pada sampel pertama dan kedua

\begin{tabular}{ccc|lc}
\hline \multirow{2}{*}{ No } & \multicolumn{2}{c}{ Data Komposisi sampel Pertama } & \multicolumn{2}{c}{ Data Komposisi sampel Kedua } \\
\cline { 2 - 5 } & Unsur & Kandungan $(\%)$ & Unsur & Kandungan $(\%)$ \\
\hline 1. & Sulfur $(\mathrm{S})$ & 0,03 & Sulfur $(\mathrm{S})$ & 0,02 \\
2. & Mangan $(\mathrm{Mn})$ & 0,08 & Mangan $(\mathrm{Mn})$ & 0,03 \\
3. & Besi $(\mathrm{Fe})$ & 0,47 & Besi $(\mathrm{Fe})$ & 0,32 \\
4. & Nikel $(\mathrm{Ni})$ & 0,38 & Nikel $(\mathrm{Ni})$ & 0,36 \\
5. & Tembaga $(\mathrm{Cu})$ & 57,78 & Tembaga $(\mathrm{Cu})$ & 57,35 \\
6. & Seng $(\mathrm{Zn})$ & 38,43 & Seng $(\mathrm{Zn})$ & 39,83 \\
7. & Timah $(\mathrm{Sn})$ & 0,78 & Timah $(\mathrm{Sn})$ & 0,57 \\
8. & Timbal $(\mathrm{Pb})$ & 1,79 & Timbal $(\mathrm{Pb})$ & 1,44 \\
\hline
\end{tabular}

Dari hasil pengujian kompisisi kimia terdapat 8 unsur, tetapi hanya unsur yang paling berpengaruh pada kuningan yaitu $\mathrm{Zn}, \mathrm{Pb}, \mathrm{Sn}, \mathrm{Fe}$, dan $\mathrm{Ni}$ yang paling dominan. Pada Tabel 2 adalah pengaruh Seng (Zn) sebesar $38,43 \%$ yang mana merupakan sampel pertama, dan 39,83\% pada sampel kedua yang menaikan nilai tensile atau kekuatan tarik pada produk kuningan. Pengaruh Timbal (Pb) 1,79\% pada sampel pertama dan 1,44\% pada sampel kedua mempunyai pengaruh baik karena dapat meningkatkan machinability, surface finish, dan ketahanan terhadap korosi, membuat kuningan lebih keras dan membuat struktur internal yang lebih kecil sehingga kuningan dapat dibentuk berulang dalam proses yang disebut penempaan. Pengaruh Timah Putih (Sn) sebesar 0,78 pada sampel pertama dan 0,57 pada sample kedua mempunyai pengaruh baik dalam meningkatkan 
ketahanan korosi dan meningkatkan kekerasan coran kuningan. Pengaruh Besi (Fe) sebesar 0,47 \% pada sampel pertama dan $0,32 \%$ pada sampel kedua yaitu menurunkan sifat mekanis, penurunan kekuatan tarik, timbulnya bintik keras pada hasil produk coran kuningan, dan meningkatnya cacat porositas. Pengaruh Nikel (Ni) sebesar $0,38 \%$ pada sampel pertama dan $0,36 \%$ pada sampel kedua yakni memperbaiki sifat - sifat atau karakteristik coran, meningkatkan impact, namun nikel mempunyai sifat kelelahan (fatique) yang tinggi tapi tidak dapat dikeraskan.

\section{CONCLUSIONS}

Struktur mikro kuningan terdiri dari fasa proeutektik $\alpha$, fasa $\beta$ dan Timbal. Fasa proeutektik $\alpha$ mempunyai struktur FCC dan fasa $\beta$ mempunyai struktur BCC. Fasa proeutektik $\alpha$ ditunjukan dengan warna putih dan fasa $\beta$ ditunjukan dengan warna gelap, sedangkan Timbal ditunjukan dengan titik-titik warna hitam kelam. Fasa proeutektik $\alpha$ lebih dominan pada setiap sampelnya diikuti fasa $\beta$ dan Timbal dalam bentuk partikel. Pada sampel kedua didapat struktur mikro yang berbeda, dari unsur fasa proeutektik $\alpha$ yang kecil dan sedikit memanjang dan fasa $\beta$ yang menjadi sedikit. Hal tersebut dikarenakan perbedaan sampel produk yang diuji.

\section{REFERENCES}

Konen, Radomila, \& Fintov, Stanislava. (2012). Copper and Copper Alloys: Casting, Classification and Characteristic Microstructures. Copp. Alloy.-Early Appl. Curr. Perform.-Enhancing Process, 3-30

Nugroho, Untung. (2010). Pengaruh Struktur Mikro Dan Kandungan Karbon Pada Kekerasan Coran Kuningan. Jakarta: Fakultas Industri, Universitas Gunadarma.

Pantazopoulos, G. and Vazdirvanidis, A. (2008). Characterization of the Microstructural Aspects of Machinable Phase Brass. Microscopy and Analysis 22(5):13-16.

Setiawan, H. (2013). Pengujian Kekuatan Tarik, Kekerasan, dan Struktur Mikro Produk Cor Propeler Kuningan. Simetris: Jurnal Teknik Mesin, Elektro dan Ilmu Komputer, 3(1), 71-81. 